\title{
The Relation of Erythritol Usage to Virulence in the Brucellas
}

\author{
By A. E. WILLIAMS, J. KEPPIE aNd H. SMITH \\ Microbiological Research Establishment, Porton, Salisbury, Wiltshire
}

(27 July 1964)

\section{SUMMARY}

Erythritol stimulated the growth of virulent strains of Brucella abortus more than that of attenuated strains. No similar correlation existed between virulence and response to erythritol with strains of $B$. melitensis and $B$. suis; these were stimulated indiscriminately by erythritol.

Erythritol was not detected in extracts of bovine white blood cells and hence is unlikely to be connected with the primary invasive process of intraphagocytic survival and growth of $\boldsymbol{B}$. abortus. However, ultrafiltrates from extracts of bovine white blood cells stimulated the growth of $B$. abortus in laboratory media.

\section{INTRODUCTION}

The presence of erythritol-a growth stimulant for brucellas-in susceptible tissues appears to explain the localization of brucellas in the placenta and male genitalia of susceptible animal species; those animal species which do not suffer intense placentitis in brucellosis had no detectable erythritol in their placentas (Smith et al. 1962; Pearce et al. 1962; Williams, Keppie \& Smith, 1962; Keppie, Williams, Witt \& Smith, 1965). In these studies, single virulent strains of Brucella abortus, $\boldsymbol{B}$. melitensis and $\boldsymbol{B}$. suis were used. The effect of erythritol on the growth of a number of strains has been investigated to see whether a connexion exists between erythritol usage and virulence. McCullough \& Beal (1951) had already shown that the growth of four different virulent strains of each Brucella species was stimulated by erythritol when it was present as the sole carbon and energy source in a simple basal medium. In the present studies, we have examined the effect of erythritol on the growth of several virulent and avirulent strains of Brucella in media containing adequate glucose. Some correlation was found between the virulence of various strains of $\boldsymbol{B}$. abortus and their growth response to erythritol. These findings could not be extended to strains of $B$. melitensis and $B$. suis but they prompted the investigation reported in this paper.

The ability of various strains of Brucella abortus to survive phagocytosis and multiply within bovine phagocytes is correlated with their virulence and appears to rely to some extent on protective cell-wall materials which may be produced more by virulent than by avirulent cells (Smith \& Fitzgeorge, 1964; Macrae \& Smith, 1964). However, avirulent cells produce some protective material and a factor which may also contribute to the different behaviour of avirulent and virulent strains on phagocytosis might be a superior ability of the latter to exploit the growth conditions of the host's phagocytes, while the bactericidal mechanisms of the latter are neutralized by the cell-wall materials. This hypothesis would be supported if the phagocytes contained small amounts of erythritol which could stimulate the growth of virulent rather than avirulent strains of $\boldsymbol{B}$. abortus. Hence, extracts of white blood cells and other constituents of blood were examined for the presence 
of small amounts of erythritol and for the ability to stimulate the growth of virulent and avirulent strains of $\boldsymbol{B}$, abortus in laboratory media.

\section{METHODS}

Strains of Brucella. The virulence of the Brucella strains was determined in guinea pigs as follows; a dose of $3 \times 10^{6}$ for Brucella abortus and $B$. melitensis, and $1 \times 10^{3}$ for $B$. suis was injected intramuscularly into guinea pigs $(400 \pm 50 \mathrm{~g}$.). Three weeks later the average count in the spleens of these animals was determined by the culture of suitable dilutions of macerated spleen. The strains were designated virulent when the spleen counts were greater than $3 \times 10^{4}$, attenuated when greater than $1 \times 10^{3}$ and less than $3 \times 10^{4}$, and avirulent when less than $1 \times 10^{3}$ (cf. Table II of Smith \& Fitzgeorge, 1964):
B. abortus strains
Virulent Attenuated Avirulent
B. melitensis strains
Virulent Attenuated Avirulent
B. suis strains
Virulent Attenuated Avirulent

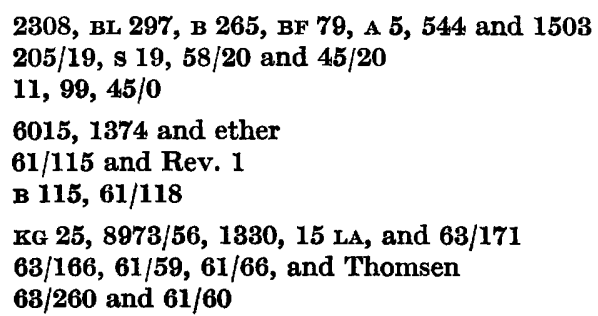

Erythritol was supplied by G. T. Gurr Ltd. and recrystallized from moist acetone.

\section{Tests for ability of materials to stimulate the growth of Brucella in vitro}

(a) Viable count method. The method has been described previously (Williams et al. 1962). The basal medium was a mixture of tryptic digest meat broth ( 1 part) and isotonic saline (2 parts); the inoculum was 100 organisms $/ \mathrm{ml}$.

(b) Turbidimetric methods. Shake cultures in cuvette-flasks were used (Copeland, 1955). Optically matched Pyrex test-tubes were fixed to the sides of $50 \mathrm{ml}$. conical flasks. Medium, inoculated with the test organism (see below) was distributed into the cuvette-flasks $(10 \mathrm{ml}$. per flask). Experimental flasks received erythritol in Locke solution $(0.2 \mathrm{ml}$.). Control flasks received Locke solution $(0.2 \mathrm{ml}$.). The flasks were incubated on a horizontal shaker at $37^{\circ}$. Strains requiring added $\mathrm{CO}_{2}$ for growth were incubated in sealed aluminium boxes gassed with air containing $5 \% \mathrm{CO}_{2}$. When turbidity readings were required the flasks were turned through approximately $120^{\circ}$, thus transferring the culture to the side-arm, and turbidimetric readings were obtained directly in the Coleman spectrophotometer. The flasks were then returned to the shaker when subsequent readings were required for the preparation of growth curves. The optical densities of duplicate flasks varied by less than $3 \%$. When required (see Table 2) regression coefficients for the log phase of growth were calculated from the curves between 17 and $25 \mathrm{hr}$ and the ratios of the growth rates with and without erythritol were obtained.

Two media were used in this work.

Medium (1): a mixture of tryptic digest meat broth with Locke solution ( $1+1$ by vol.) with an inoculum of $1-2 \times 10^{6} / \mathrm{ml}$. Turbidimetric readings were made at 570 $\mathrm{m} \mu$.

Medium (2): a modified form of that used by Rode, Oglesby \& Schuhardt (1950). 
A glutamate-free modification of this medium (Anderson \& Smith, 1965) would not support the growth of avirulent strains of Brucella abortus; hence $100 \mu \mathrm{g}$. L-glutamic acid $/ \mathrm{ml}$. was added. The modified medium differed from that of Rode et al. (1950) as follows. D-glucose $7.0 \mathrm{mg} . / \mathrm{ml}$. (instead of $4.0 \mathrm{mg} . / \mathrm{ml}$.); ammonium sulphate $1.35 \mathrm{mg} . / \mathrm{ml}$. (instead of nil); L-glutamic acid $100 \mu \mathrm{g} . / \mathrm{ml}$. (instead of $3000 \mu \mathrm{g}$. DL-glutamic acid $/ \mathrm{ml}$.). A concentrated $(4 \times)$ stock solution, minus the biotin, glucose and glutamic acid, was stored at $-20^{\circ}$. A supply of medium for 2 weeks was prepared from the stock solution by dilution, addition of biotin and filtration through a 'Millipore' filter. The filtered solution was stable at $0-4^{\circ}$ for 14 days. Glucose and glutamate were added before each experiment and the medium refiltered. The medium was inoculated with $2 \times 10^{7} / \mathrm{ml}$. and extinction measurements on cultures were made at $430 \mathrm{~m} \mu$.

Estimation of erythritol. The method has been described by Williams et al. (1962).

\section{Preparation of cell extracts from bovine blood for biological and chemical analysis}

Differential centrifugation of blood yielded large quantities of white blood cells which were purified from red blood cells. The white blood cells were disrupted ultrasonically and the ultrafiltrates of the extracts were examined. Red blood cells were also obtained and disrupted by freezing and thawing.

Citrated $(0.25 \%)$ bovine blood (10 1.) was centrifuged for $60 \mathrm{~min}$. at $2^{\circ}$ in an M.S.E. Major centrifuge. The plasma was removed and a $200 \mathrm{ml}$. sample frozen at $-20^{\circ}$; a $200 \mathrm{ml}$. sample of the red blood cells also was frozen at $-20^{\circ}$. The 'buffy coat' (300-750 ml.) containing the majority of white blood cells was removed by pipette and centrifuged at $27,000 \mathrm{rev} . / \mathrm{min}$. for $60 \mathrm{~min}$. in the 30 rotor of a Spinco ultracentrifuge. The plasma from the deposit was decanted revealing the white blood cells as a coherent 'skin' (2-5 mm. thick) on the surface of the remaining erythocytes. This skin was tipped from each tube on to a microscope slide $\left(3 \times 1 \frac{1}{2}\right.$ in. $)$, and the slide inverted on a white enamel tray. Careful removal of the slide showed a contaminating layer of erythrocytes on the lower surface of the leucocyte skin. By gently drawing the edges of two other slides across this exposed surface (beginning at the centre and moving in opposite directions) the majority of these erythrocytes were removed. These manipulations were carried out at $0-4^{\circ}$. The 'pure' leucocyte preparation was frozen at $-20^{\circ}$. A yield of $2-4 \times 10^{10}$ leucocytes was obtained from 101 . of bovine blood. Haemocytometer counts showed that samples prepared by this method had w.B.c.: R.B.c. ratios which varied from 2:1 to 1:5. Dye-exclusion tests with eosin indicated that 50-75\% of leucocytes in the final sample were viable.

The three fractions were treated as follows:

Leucocyte fraction. This was thawed and homogenized by maceration in an M.S.E. overhead macerator with the minimum quantity (about $20 \mathrm{ml}$.) of isotonic phosphate saline buffer $\left(\mathrm{NaCl} 7 \cdot 5, \mathrm{Na}_{2} \mathrm{HPO}_{4} 1 \cdot 42, \mathrm{KH}_{2} \mathrm{PO}_{4} 1 \cdot 36\right.$ g. $/ 1$; $\mathrm{pH} 7 \cdot 4$ with $40 \%$, w/v, $\mathrm{NaOH}$ ). The cooled cell suspension was stirred magnetically and treated ultrasonically for $15 \mathrm{~min}$. with the M.S.E. Mullard ultrasonic disintegrator as described by Smith, Keppie, Cocking \& Witt (1960). Haemocytometer counts showed that $99.9 \%$ of the leucocytes had disintegrated. The extract was centrifuged at $27,000 \mathrm{rev} . / \mathrm{min}$. for $60 \mathrm{~min}$. int he 30 rotor of a Spinco ultracentrifuge. The supernatant fluid was ultrafiltered at $0-2^{\circ}$ and the ultrafiltrate stored at $-20^{\circ}$. 
Erythrocyte fraction. This $\left(1 \times 10^{10} \mathrm{red}\right.$ cells $/ \mathrm{ml}$. disrupted by the freezing) was thawed and centrifuged at $27,000 \mathrm{rev} . / \mathrm{min}$. for $60 \mathrm{~min}$. in the 30 rotor of a Spinco ultracentrifuge. Diffusates, prepared by dialysing the supernatant fluid $(200 \mathrm{ml}$.) against de-ionized water $(3 \times 400 \mathrm{ml}$. over 3 days), were freeze dried. To estimate the total amount of diffusible material in the extracts (so that freeze-dried diffusates could be redissolved at a strength $\equiv$ the original extracts) the losses in dry weight $\left(105^{\circ}, 16 \mathrm{hr}\right)$ of small samples of the extracts were obtained after exhaustive dialysis.

Plasma. A diffusate was obtained from the plasma by treating it as described for the extract of erythrocytes.

\section{RESULTS}

The effect of erythritol on the growth of strains of Brucella abortus after 24. $\mathrm{hr}$ in a broth medium in vitro

The results in Table 1 show that there was some correlation between degree of virulence for guinea pigs and enhancement of growth by erythritol in medium (1), i.e. tryptic digest meat broth + Locke solution $(1+1)$. At erythritol concentrations higher than those shown in Table $1(2-10 \mu \mathrm{mole} / \mathrm{ml}$.) some stimulation of the growth of the relatively avirulent strains was observed but the degree of stimulation was smaller than that occurring with the more virulent strains.

Table 1. The relation between the virulence of Brucella abortus strains and growth enhancement by erythritol

\begin{tabular}{|c|c|c|}
\hline \multirow[b]{2}{*}{ Strain } & \multicolumn{2}{|c|}{ Erythritol concentration } \\
\hline & $1 \mu \mathrm{mole} / \mathrm{ml}$ & $0.1 \mu \mathrm{mole} / \mathrm{ml}$ \\
\hline \multicolumn{3}{|l|}{ Virulent } \\
\hline 2808 & $90 *$ & 36 \\
\hline BL 297 & 88 & $\mathbf{8 9}$ \\
\hline B 265 & $\mathbf{5 9}$ & 30 \\
\hline BF 79 & 55 & 15 \\
\hline A 5 & 49 & 18 \\
\hline 544 & 47 & 19 \\
\hline 1503 & $\mathbf{3 9}$ & 17 \\
\hline \multicolumn{3}{|c|}{ Attenuated } \\
\hline $205 / 19$ & 24 & 5 \\
\hline $45 / 20$ & $\mathbf{3}$ & -15 \\
\hline $\mathbf{8} 19$ & -2 & -2 \\
\hline $58 / 20$ & -7 & -2 \\
\hline \multicolumn{3}{|l|}{ Avirulent } \\
\hline 11 & 20 & $\mathbf{8}$ \\
\hline 99 & $\mathbf{0}$ & -1 \\
\hline $45 / 0$ & 6 & 6 \\
\hline
\end{tabular}

* Growth enhancement by erythritol in medium (1), i.e. tryptic digest meat broth + Locke solution $(1+1)$ after $24 \mathrm{hr}$ incubation measured as

$$
\frac{\text { Optical density of (sample-control) }}{\text { Optical density of control }} \times \frac{100}{1} \text {. }
$$

All strains grew at approximately the same rate in the basal medium. Results are averages of several experiments. 
The effect of erythritol on the growth rate of strains of Brucella abortus in a defined medium

The growth rates of various strains of Brucella abortus were measured in medium (2) with and without erythritol. The weighted means of the ratios of the growth rates from several experiments (Table 2) again indicated the greater response of the virulent strains to erythritol.

Table 2. Growth rate response to erythritol by Brucella abortus strains in a defined medium (medium (2))

$\begin{array}{lc}\begin{array}{c}\text { Strain } \\ \text { Virulent } \\ \text { BL 297 }\end{array} & \text { Weighted mean* } \\ \mathbf{5 4 4} & \mathbf{1 \cdot 8 2} \\ \text { Attenuated } & \mathbf{1 . 4 7} \\ \mathbf{2 0 5 / 1 9} & \\ \mathbf{S ~ 1 9} & \mathbf{1 . 0 1} \\ \mathbf{5 8 / 2 0} & \mathbf{0 . 9 6} \\ \text { Avirulent } & \mathbf{1 . 1 1} \\ \mathbf{1 1} & \\ \mathbf{9 9} & \mathbf{1 . 0 3} \\ \mathbf{4 5 / 0} & \mathbf{1 . 0 3} \\ \end{array}$

All strains grew at approximately the same rate in the basal medium.

* Gradient log phase with erythritol (2 $\mu \mathrm{mole} / \mathrm{ml}$.

Gradient log phase without erythritol

The growth response to erythritol of strains of Brucella melitensis and B. suis of differing virulence

The effect of erythritol on the growth of strains of Brucella melitensis and B. suis was investigated under two sets of growth conditions: (1) low erythritol concentrations and small inoculum of organisms-growth being measured by colony count; and (2) high erythritol concentration and large inoculum of organisms-growth being measured turbidimetrically. The results in Table 3 show that all the $\boldsymbol{B}$. melitensis and $B$. suis strains were stimulated to a greater or lesser extent by erythritol irrespective of their virulence for the guinea pig.

The erythritol content of fractions from bovine blood and their growthpromoting activity for Brucella abortus

Diffusates or ultrafiltrates prepared from white blood cells, red blood cells and plasma obtained from several batches of bovine blood were examined chemically for the presence of erythritol. Parallel biological tests were also carried out to see whether these extracts stimulated the growth of virulent and avirulent strains of Brucella abortus in a broth medium. The results are shown in Table 4. Erythritol was not detected ( $<5 \mu \mathrm{g} . / \mathrm{ml}$. extract) in any of the leucocyte, erythrocyte or plasma samples. However, the four leucocyte extracts, even when considerably diluted, caused significant stimulation of the growth of virulent and avirulent strains of $B$. abortus. In the same experiments, erythritol stimulated only the virulent strains (544 and 2308) and an equivalent amount of glucose had no effect on any 
Table 3. The growth response to erythritol of strains of Brucella melitensis and $B$. suis

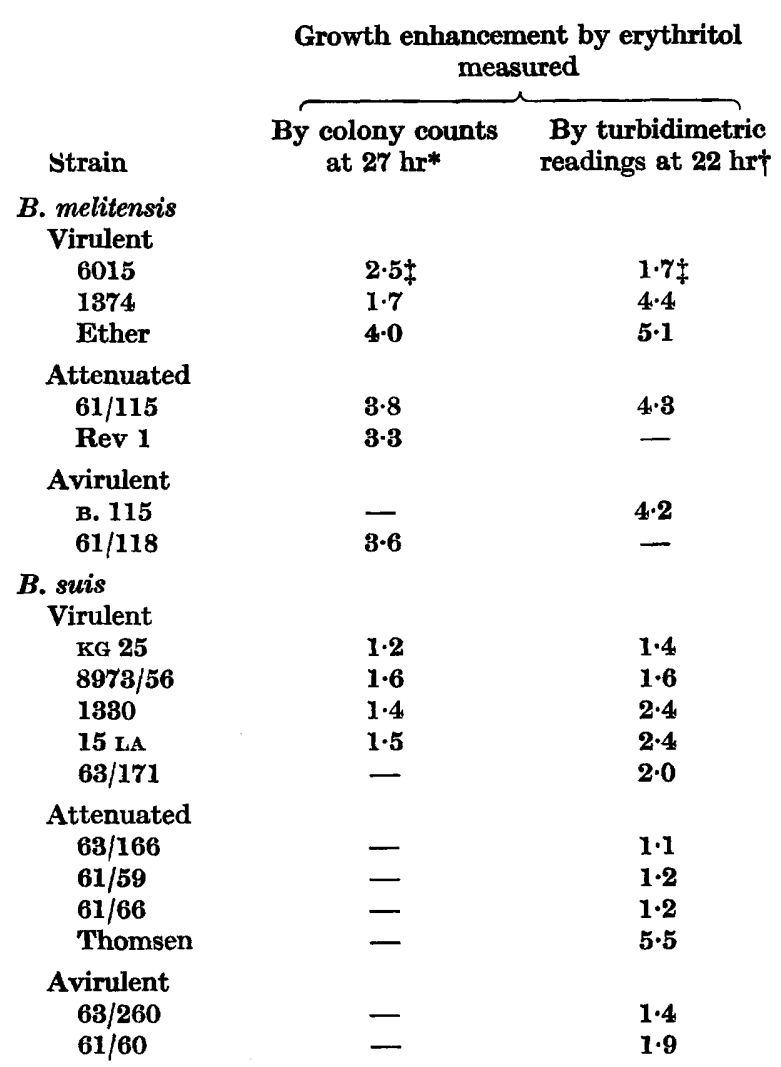

* Medium: tryptic digest meat broth (1 vol.) and isotonic saline (2 vol.); inoculum 100 organisms per ml.; erythritol $0.065 \mu$ mole $/ \mathrm{ml}$.

$\dagger$ Medium (2) was used; inoculum $2 \times 10^{7} / \mathrm{ml}$; erythritol $2 \mu \mathrm{mole} / \mathrm{ml}$.

$\$$ These results are the means of several similar experiments measured as

$$
\frac{\text { population of treated sample }}{\text { population of control }} \text {. }
$$

Table 4. The growth-enhancing effect on Brucella abortus of diffusates, from extracts of the white blood cells and other fractions of bovine blood, all with an erythritol content of less than $5 \mu \mathrm{g} . / \mathrm{ml}$.

\begin{tabular}{|c|c|}
\hline \multicolumn{2}{|c|}{ White blood cell diffusates } \\
\hline $\begin{array}{l}\text { w.B.c. count } \\
\text { per ml. }\end{array}$ & $\begin{array}{l}\text { R.B.C. count } \\
\text { per ml. }\end{array}$ \\
\hline $8 \times 10^{8}$ & $1.7 \times 10^{2}$ \\
\hline $\begin{array}{l}5 \times 10^{8} \\
5 \times 10^{8}\end{array}$ & $\begin{array}{l}2.6 \times 10^{9} \\
2.7 \times 10^{8}\end{array}$ \\
\hline $6 \times 10^{8}$ & - \\
\hline
\end{tabular}

Four red blood cell diffusates

Four plasma diffusates
Highest dilution enhancing growth (twofold) at $24 \mathrm{hr} *$

\begin{tabular}{|c|c|c|c|}
\hline \multicolumn{2}{|c|}{ Virulent } & \multicolumn{2}{|c|}{ Attenuated } \\
\hline 544 & 2308 & $45 / 0$ & $58 / 20$ \\
\hline $1 / 60$ & $1 / 60$ & $1 / 60$ & $1 / 60$ \\
\hline $1 / 60$ & $1 / 60$ & $1 / 60$ & $1 / 60$ \\
\hline - & $1 / 60$ & $\mathbf{1} / \mathbf{3 0}$ & $\mathbf{1} / \mathbf{3 0}$ \\
\hline & $1 / 60$ & $1 / 30$ & $\mathbf{1} / \mathbf{3 0}$ \\
\hline
\end{tabular}

All inactive $1 / 10$ for 2308

All inactive 1/10 for 2308

* Growth measured by viable counts; medium tryptic digest meat broth (1 vol.) and isotonic saline (2 vol.); inoculum 100 organisms/ml. 
strains. The factor(s) capable of stimulating both virulent and avirulent strains of $\boldsymbol{B}$. abortus was apparently confined to leucocytes as all erythrocyte and plasma fractions were inactive.

\section{DISCUSSION}

The finding that erythritol stimulates virulent more than attenuated strains of Brucella abortus is interesting in view of the previous investigations (Williams et al. 1962) suggesting that the presence of foetal erythritol is a cause of the localization of $\boldsymbol{B}$. abortus in bovine foetal tissue. However, the lack of erythritol in bovine white blood cells suggests that this differential effect of erythritol on virulent $B$. abortus strains probably has no relevance to the primary invasive process of intraphagocytic survival and growth. In contrast to these results with $B$. abortus there seems to be no correlation between growth stimulation by erythritol and the virulence of various strains of $\boldsymbol{B}$. melitensis and of $\boldsymbol{B}$. suis.

The fact that extracts of the mixed cell population of bovine 'buffy coat' stimulate the growth of Brucella abortus is interesting. If the same growth-stimulating activity were found in extracts of phagocytes purified from the buffy coat, it might have some relevance to the intracellular growth of virulent $B$. abortus.

A factor that may be involved in the phenomenon of intracellular survival and growth in bovine phagocytes is glutamic acid metabolism. Olsen (1951) showed that there was a correlation between virulence and high oxidative rate of glutamic acid in Brucella abortus and we have shown the influence of $L$-glutamic acid on the growth of avirulent strains in a synthetic medium. Furthermore, Anderson \& Smith (1965) have shown that stimulation of growth of a virulent strain by erythritol is inhibited by high concentrations of glutamic acid. Wilson \& Dasinger (1960) have discussed the influence of glutamic acid in relation to intracellular growth. They suggest that the rapid removal of intracellular glutamate by avirulent strains might produce conditions inimical to the organisms' growth.

We are indebted to Dr W. J. Brinley Morgan, Professor J. B. Wilson and Dr J. H. Payne for providing strains and to Miss G. R. Fanstone, Mrs P. Stenhouse, Miss A. D. Rawkins and Mr G. Wilkins for excellent technical assistance. Statistical analysis was done by our colleague Mr S. Peto. Part of this work was used by one of us (A.E.W.) in a thesis submitted for the degree of Doctor of Philosophy in the University of London.

\section{REFERENCES}

Anderson, J. D. \& SMrth, H. (1965). The metabolism of erythritol by a virulent strain of Brucella abortus. J. gen. Microbiol. 38, 1.

Copeland, J. M. (1955). Characterization of a stimulating factor for Brucella abortus from yeast autolysate. M.S. Thesis Univ. Wis. Madison, Wis.

Keppie, J., Williams, A. E., Witt, K. \& Sмith, H. (1965). The role of erythritol in the tissue localization of the brucellae. Brit. J. exp. Path. (in the Press).

Macrae, R. M. \& Smith, H. (1964). The chemical basis of the virulence of Brucella abortus. VI. Studies on immunity and intracellular growth. Brit. J. exp. Path. Vol. 45.

McCullough, N. B. \& BEAL, G. A. (1951). Growth and manometer studies of carbohydrate utilization by Brucella. J. infect. Dis. 89, 266.

Olsen, C. B. (1951). The aerobic metabolism of Brucella abortus. M.S. Thesis Univ. Wis. Madison, Wis. 
Pearce, J. H., Wiluiams, A. E., Harris-Smith, P. W., Fitzgeorge, R. B. \& Smith, H. (1962). The chemical basis of the virulence of $B r$. abortus. II. Erythritol, a constituent of bovine foetal fluids which stimulate the growth of $\mathrm{Br}$. abortus in bovine phagocytes. Brit. J. exp. Path. 43, 31.

Rode, L. J., Oglesby, G. \& Schuhardt, V. T. (1950). Cultivation of Brucella on chemically defined media. J. Bact. 60, 661 .

Smith, H. \& Fitzgeorge, R. B. (1964). The chemical basis of the virulence of Brucella abortus. V. The basis of intracellular survival and growth in bovine phagocytes. Brit. J. exp. Path. 45, 174.

Smith, H., Keppie, J., Cocking, E. C. \& WitT, K. (1960). The chemical basis of the virulence of Pasteurella pestis. I. The isolation and the aggressive properties of Past. pestis and its products from infected guinea pigs. Brit. J. exp. Path. 41, 452.

Smith, H., Wiluiams, A. E., Pearce, J. H., Keppie, J., Harris-Smith, P. W., Fitzgeorge, R. B. \& WrTt, K. (1962). Foetal erythritol: a cause of the localization of Brucella abortus in bovine contagious abortion. Nature, Lond. 193, 47.

Williams, A. E., KePpIE, J. \& Smith, H. (1962). The chemical basis of the virulence of Brucella abortus. III. Foetal erythritol, a cause of the localization of Brucella abortus in pregnant cows. Brit. J. exp. Path. 43, 530.

Wirson, J. B. \& DASINGER, B. L. (1960). Biochemical properties of virulent and avirulent strains of Brucellae. Ann. N.Y. Acad. Sci. 88, Art. 5, 1155. 